Research article

\title{
The dynamics of urban household energy poverty and energy transition in Mozambique
}

\author{
Carlos Shenga,1* Matthew Cotton, ${ }^{2}$ Joshua Kirshner ${ }^{3}$ and Lorraine \\ Howe 4
}

1 Centre for Research on Governance and Development, Mozambique and University Joaquim Chissano, Mozambique

2 Teesside University

3 University of York

4 Centre for Research on Governance and Development, Mozambique

\begin{abstract}
Among developing nations, Mozambique has set an ambitious target to achieve universal energy access by 2030 and thus meet the United Nations' Sustainable Development Goal 7 to ensure access to affordable, reliable, sustainable and modern energy for all. By the end of 2024 the government expects to double domestic electricity access to 64 per cent of the population. Yet the quantitative evaluation of electricity access rates belies challenges of energy service affordability, household budgeting, and fuel and technology availability and choice. With growing concern over issues of energy poverty and energy justice for vulnerable low-income communities, this study provides an in-depth qualitative evaluation of the lived experience of energy access and energy poverty in urban Mozambique, through household interviews in the four biggest cities in the country. There are three main findings. First, we find qualitative indicators of energy wellbeing in urban households, however this energy wellbeing is divided politically - with energy service benefits felt most strongly in municipalities governed by the dominant party: Frelimo. Second, sustainable energy transitions in urban households are limited by the low uptake of renewable energy sources. Third, despite the majority having gridconnected electricity access, many urban households continue to use non-renewable fuels (gas and charcoal) for cooking and view renewable sources, such as solar panels, as a short-term energy fix. We argue therefore that greater policy emphasis upon smallscale renewable energy investment, uptake and implementation in urban localities is needed to spur action on sustainable energy poverty alleviation.
\end{abstract}

Keywords: energy poverty, energy transition, energy services, Mozambique, SDG7.

Copyright: (C) 2022, Author(s). This is an open access article distributed under the terms of the Creative Commons Attribution 4.0 License, which permits unrestricted use, distribution, and reproduction in any medium, provided the original author and source are credited. 


\section{Introduction - global energy access and energy poverty}

The global energy system faces three primary challenges in meeting the United Nation's Sustainable Development Goal 7 to 'ensure access to affordable, reliable, sustainable and modern energy'. It also faces an urgent need for energy transition to improve the scale of energy service provision, reduce the carbon-intensity of fuel sources, and provide fair and equal access. These include: the growing risk of energy supply disruption, environmental damage caused by energy production and use (notably towards climate change and air pollution), and alleviating entrenched energy poverty (Birol, 2007). The last of these - energy poverty - concerns a complex set of overlapping vulnerabilities and justice concerns, necessitating a multi-disciplinary analysis (Ambrose and Marchand, 2017) of how national energy policy frameworks intersect with domestic income, welfare, and social practices of energy use.

In the social analysis of energy poverty in societies undergoing rapid economic development there are a range of factors that influence energy security and affordability outcomes for marginalised rural and urban communities. As Ochoa and Graizbord Ed (2016) and Nussbaumer et al. (2012) argue, energy poverty is a condition of deprivation from energy services, or as Oliveras et al. (2020: 1) put it: 'the inability of a household to secure a socially and materially required level of energy services in the home'. The modernisation and expansion of energy services is an essential component to alleviating energy poverty globally (Birol, 2007). Reducing incidence of energy poverty has a measurable impact upon positive health and education outcomes; with electricity access providing a more substantial benefit than total energy use (ibid). Providing household electricity connections allows access to multiple energy services. These include telecommunications, internet access (with associated benefits to education, recreation and domestic finance), refrigeration, lighting, and cooking technologies. The local economic development potential of even intermittent electricity access is substantial. Moreover, reduction in the use of domestic biomass fuels (notably charcoal) has potential respiratory health benefits, reduces risks of injury or property damage from fire, and ameliorates forest habitats from deforestation (Mensah et al., 2020). These benefits are now firmly established in the political imagination, such that expansion of grid access is prioritised as a matter of social justice for development organisations and state authorities, as well as a popular (and vote-winning) issue amongst urban and rural publics (Imami et al., 2020). In short, expanding grid connections has become a political priority within development policy networks.

Progress towards electrification is commonly measured by total connections and/or per capita percentage of connected users (World Bank, 2017). Yet this belies the complicated picture of how electricity is experienced in the home, particularly for those experiencing electricity access for the first time. Experiencing electricity services is not as simple as having a grid connection, but rather is mediated through a range of interrelated factors. These include:

- Economic factors: such as the relationship between (often state or parastatal institution-controlled) prices and household income (Castán Broto et al., 2020; Barnes et al., 2011; Okushima, 2016), fuel choice constraints and price fluctuations (for example: Mulenga et al., 2019), and competition for energy services between domestic and industrial users (Salite et al., 2021).

- Technical factors: such as balancing of centralised (usually fossil-fuel powered) electricity generation and decentralised (often renewable) electricity grids (Brisbois, 2020; Williams and Short, 2020), the public expenditure contribution differential between fossil fuel subsidisation and renewables-based electricity 
access (Schmidt et al., 2017), the challenges of maintaining aging assets and system maintenance (Salite et al., 2021), and the management of supply and demand disruptions (and associated risks such as appliance damage from voltage fluctuations) (Chaurey et al., 2004).

- Socio-cultural factors: such as autonomy and decision-making capacity over household expenditure (such as pre-paid electricity meters), experiences of intermittency (Abi Ghanem, 2018), trust in state institutions (Bronfman et al., 2015), and social practices of energy use (including cooking and heating) (Herrington et al., 2017).

- Geopolitical factors: such as infrastructure system expansion shaped by the spatial distribution of energy services designated under former colonial planning regimes (Power and Kirshner, 2019), geopolitics of cross-border energy service agreements and associated effects on prices, and the deliberate politicisation of energy pricing and distribution within electoral systems (Borowski, 2021).

Understanding how these factors are experienced and interpreted at the household level and how the dynamics of electricity access influence energy poverty outcomes is a growing area in the field of energy justice (e.g., Bouzarovski, 2014; Bouzarovski, 2018) in which concepts of energy wellbeing are of growing concern (Brand-Correa and Steinberger, 2017; Samarakoon, 2019). Research within energy justice around electrification specifically (notably Salite et al., 2021; Tarekegne, 2020), shows that electrification planning commonly emphasises techno-economic criteria and the structural constraints to energy infrastructure provision - often failing to provide energy services to those who need it the most, further exacerbating energy access inequalities at a local level and sacrificing the wellbeing of vulnerable communities for the sake of profit maximisation and/or the political prestige associated with large-scale centralised infrastructure provision (e.g. Cotton et al., 2021). The normative dimensions of energy provision concerning the distribution of energy infrastructure and services, the political capacity of vulnerable communities to control energy pricing and electricity access, are matters of just social development policy; and they come to the fore of system planning, regulation, and technological development across the Global South. The interplay between broader national and international institutional frameworks, market dynamics and social welfare systems with household experiences provides the nexus between energy poverty and energy justice research.

In this paper we explore these dynamics through qualitative research in Mozambique. Mozambique has a national electricity access rate of only 35 per cent, with large disparities between urban and rural locations (IEA, 2020). The government has set an ambitious target to achieve 64 per cent access by 2024 and universal access by 2030 (EDM, 2020a). It therefore provides a critical example of expanding domestic electricity access for energy poverty alleviation in the developing world context.

\section{Likely explanatory factors of energy poverty in Mozambique}

This empirical study explores the dynamics of urban households' energy poverty in the context of an emerging, state-supported energy transition in Mozambique. There are three possible explanations of energy poverty dynamics under consideration here. The first relates to economic factors - principally household income, the second concerns energy service provision factors - particularly through the prepaid electricity system, and the third concerns geopolitical factors - including the place (municipality) where urban households are located. For the economic explanation we assume that higher household income will lead to a reduction in energy poverty and that this in turn will improve energyrelated wellbeing. When examining energy profiles among urban households in 
Mozambique previous research by Castán Broto et al. (2020) has shown that increases in income lead to higher levels of energy consumption; as found in other studies of energy poverty globally (see Barnes et al., 2011; Okushima, 2016). However, even with rising incomes, household decision-making over energy use is filtered through experiences of energy service provision (including reliability), the social practices of energy use, decision-making autonomy over fuel choice, and through interactions with state-based and parastatal institutions that govern energy pricing, domestic technologies (grid connections, meters), maintenance and repair. The quality of energy services from the state-owned energy company (Electricidade de Moçambique, EDM) influences the experience of energy poverty, alongside cost and income measures. With respect to service provision, we assume that EDM's prepaid electricity service contributes to reducing energy poverty.

The location, spatial and scalar distribution of energy services is deeply significant to the experiences of energy poverty in Mozambique. The place where households are located affects their energy wellbeing or poverty. Place matters (Goodin and Tilly, 2006). Place 'affects the consequences of action' (Therborn, 2009: 501), understood as a site that shapes meaning, memory and identity for individuals and communities (Cresswell, 2014).

We posit that Mozambique place-based factors are influenced by political jurisdiction. The governing party Frelimo rules at the national scale and has held power since national independence in 1975. After the 1994 founding multiparty election Frelimo has been shaping energy policy through its parliamentary majority and controlling its implementation through its executive branch and bureaucracy. In a country where a single party has been in power for long, the provision of energy services itself can become a tool of political control. We measure location by municipality and frame that: in municipalities governed by Frelimo, we expect to find higher levels of energy wellbeing than in those located in municipalities ruled by the opposition parties MDM and Renamo. Thomassen (2020) reflected on how having an effective party in government is linked with policy preferences of voters to public policy and as Bellinger (2021: 1144) found: 'stronger parties have the capacity to formulate policies that meet the needs of the citizenry'. If energy service provision is strong, ergo this would lead to voter satisfaction. However, the link of place and political parties is underpinned by deeper place-related forms of identity and affiliation (Thomassen, 2020; Shenga, 2020; Cresswell, 2014), including deep-rooted cultural identities tied to political party affiliation. Moreover, in Mozambique urban residents are less likely to feel affiliation to the incumbent party (Shenga, 2020). Understanding how political affiliation influences these broader economic and sociotechnical dynamics of energy poverty is a core aspect of our analysis.

\section{Studies on energy poverty in Mozambique}

Studies on energy poverty in Mozambique have been dominated by economic assessments, such as those of the World Bank, that conceptualise poverty as the absence of cash income. In Mozambique the World Bank has provided regular funding to the National Institute of Statistics (INE) to conduct Household Budget Surveys (19972019) viewing poverty within this monetary framework. The monetary approach was broadened in 2002 through the Afrobarometer individual level surveys in Mozambique. Afrobarometer use a multidimensional poverty perspective, including for example, other factors relevant to energy poverty, such as absence of cooking fuel. What is notable however, is that energy poverty research instruments reveal a preference for quantitative analysis (with notable examples including Ugembe et al., 2021; Castán Broto, et al., 2020; Salazar et al., 2017); whilst examination of energy justice, sustainability 
transitions and political power have adopted qualitative and conceptually critical approaches primarily at national and regional scales of analysis (notable examples include: Boris, 2010; Power et al., 2016; Castán Broto et al., 2018; Salite et al., 2021) - understanding the power dynamics, justice implications and policy frameworks involved in meeting SDG7 within Mozambique. This paper contributes to this emergent field of sustainable transition analysis in Mozambique, by examining lived experiences from a bottom-up, community-level perspective, through qualitative analysis of interview data collected within municipalities from the three major regions of Mozambique.

\section{Methodology}

We draw upon 120 in-depth household interviews conducted between November 2019 and March 2020 in four municipalities: Maputo City, Matola, Nampula City, and Beira. In each municipality the data collection took place in 6 neighbourhoods (bairros) selected to incorporate a mix of longer established neighbourhoods and newly-settled, expansion zones. Households were selected at random by the interviewer using a walking pattern from an established focal point (school, health centre etc) in each bairro.

Maputo City and Matola are in southern Mozambique and have been ruled by Frelimo since the first municipal elections in 1998. Maputo is the national capital and Matola its satellite city. The Nampula City and Beira municipalities are located, respectively, in the northern and central regions and, after initially being ruled by Frelimo, faced alternation of power to the opposition Renamo and MDM (from 2013 in the case of Nampula and 2003 for Beira).

Energy poverty is measured in different ways, though monetary evaluation is the most common approach emergent in the policy and practice literatures (e.g., World Bank, 2021). Monetary evaluation balances consumption and income to measure the material wellbeing of vulnerable people (Meyer \& Sullivan, 2003). The problem with this approach is that it does not identify what poor people do, or have or are (Ruggeri Laderchi et al., 2003). As Pachauri and Spreng (2003: 11) observed, 'In cases where a household is well-off and self-sufficient but is not well integrated into the market economy, it may be mistaken as poor when the monetary value of its market transactions is the basis for measuring poverty.' In Mozambique, studies using this approach have been conducted by INE through Household Budget Surveys (1997-2019). Afrobarometer has conducted six surveys (between 2002 and 2018) where it has measured (lived) poverty by the absence of: (i) cash income, (ii) medicines or medical treatment, (iii) enough food to eat, (iv) enough clean water for home use, and (v) enough fuel (electricity, gas, charcoal, or firewood) to cook food (Mattes, 2008; 2020). The last component - poverty measured by the absence of enough fuel to cook food with -addresses energy poverty.

Pachauri and Spreng (2003: 1) reviewed at least three other approaches to energy poverty than that presented in Afrobarometer. The first 'involves the estimation of basic energy needs of a household based on engineering calculations and certain normative assumptions; [the second is related] to access to different energy sources; [and the third] combines the elements of access and consumption of energy, in order to examine how these relate to the wellbeing of households'. Drawing upon energy poverty literature (e.g., Papada and Kaliampakos, 2020) we add a fourth dimension of energy needs. Our study therefore synthesises the range of quantitative measures commonly used in energy poverty evaluation studies in the region and adapts them into qualitative evaluative dimensions and indicators used to structure the interview schedule for use in the household-level data collection process. We refer to these as individual dimensions in Figure 1. 
Figure 1: Conceptual model of energy poverty and energy transition

\begin{tabular}{|l|l|l|l|l|l|}
\hline Concept & \multicolumn{2}{|l|}{ Energy poverty } & \multicolumn{2}{l|}{ Energy transition } \\
\hline Dimension & $\begin{array}{l}\text { Access to } \\
\text { energy }\end{array}$ & Energy needs & $\begin{array}{l}\text { Energy } \\
\text { consumption }\end{array}$ & $\begin{array}{l}\text { Access to } \\
\text { energy }\end{array}$ & $\begin{array}{l}\text { Alternative } \\
\text { sources of } \\
\text { energy }\end{array}$ \\
\hline Indicator & $\begin{array}{l}\text { Choice of } \\
\text { cooking } \\
\text { fuels }\end{array}$ & $\begin{array}{l}\text { Use of } \\
\text { electricity for } \\
\text { appliances } \\
\text { and small } \\
\text { businesses }\end{array}$ & $\begin{array}{l}\text { Amount spent } \\
\text { with electricity } \\
\text { per month (in } \\
\text { Meticais) }\end{array}$ & $\begin{array}{l}\text { Choice of } \\
\text { cooking } \\
\text { fuels }\end{array}$ & $\begin{array}{l}\text { Low-vs-high } \\
\text { carbon } \\
\text { intensity of } \\
\text { energy } \\
\text { sources }\end{array}$ \\
\hline
\end{tabular}

The dimension of access to energy is indicated by the choice of cooking fuel. In interviews we asked: 'What are the main things you use electricity for?' For households that reported using electricity for cooking, we assigned them to the measure choice of cooking fuels, as besides using electricity for cooking some combine it with other fuels such as gas, charcoal, and firewood. If households have access to various types of cooking fuel we conclude that this is an indicator of energy wellbeing.

For respondents who use electricity for refrigeration, television, ironing, lighting, charging phones, kettle, radio, air conditioning, small business uses or other ends, we assigned them to the dimension of energy needs. Here we decided to focus upon households that use electricity for refrigeration, air conditioning and small businesses. These appliances consume relatively higher levels of energy and cost more to use, so they constitute a good means to probe energy poverty. Secondly, many urban households in Mozambique use electricity for small, informal businesses like barracas (a kiosk selling food, drinks or other small items) and/or other services such as welding, carpentry and hairdressing. For the energy needs dimension, if households are found to use electricity for refrigeration, air conditioning or a small business we conclude this is an indicator of energy wellbeing.

Energy consumption is measured by the amount (total cost) of electricity spent per month. We asked households about their average monthly expenditure on electricity. Those households who consume higher amounts of electricity (over $1000 \mathrm{MZN}$ per month) are deemed non-energy poor, as compared to those who consume less. Our decision to view electricity expenditure over 1000 MZN per month as high is based on the country's minimum salary. The average minimum salary in 2019 (the same period as the data collection) was 6,568 MZN (US\$ 105) per month (Wagelndicator, 2021; Finscope, 2020). Removing costs for electricity, Mozambicans are left with very little cash $(5,568 \mathrm{MZN})$ for household needs such as: housing, food, water, transportation, telecommunication, municipality taxes, school fees and uniform, medical care, along with other fuels.

The concept of energy transition, according to Rutherford and Coutard (2014: 1354), can be broadly defined "as a radical, systemic and managed change towards "more sustainable" or "more effective" patterns of provision and use of energy'. In the context of Mozambique where electricity access only reaches 35 per cent of the population (IEA, 2020) the energy transition is primarily about achieving universal access (EDM, 2018). However, as seen from the national electricity transmission map (Figure 2), most electricity connections are concentrated in urban centres where about a third (33 per cent) of the population resides (INE, 2019). 
p. 7. The dynamics of urban household energy poverty and energy transition in Mozambique

Figure 2: Mozambique National Electricity Grid

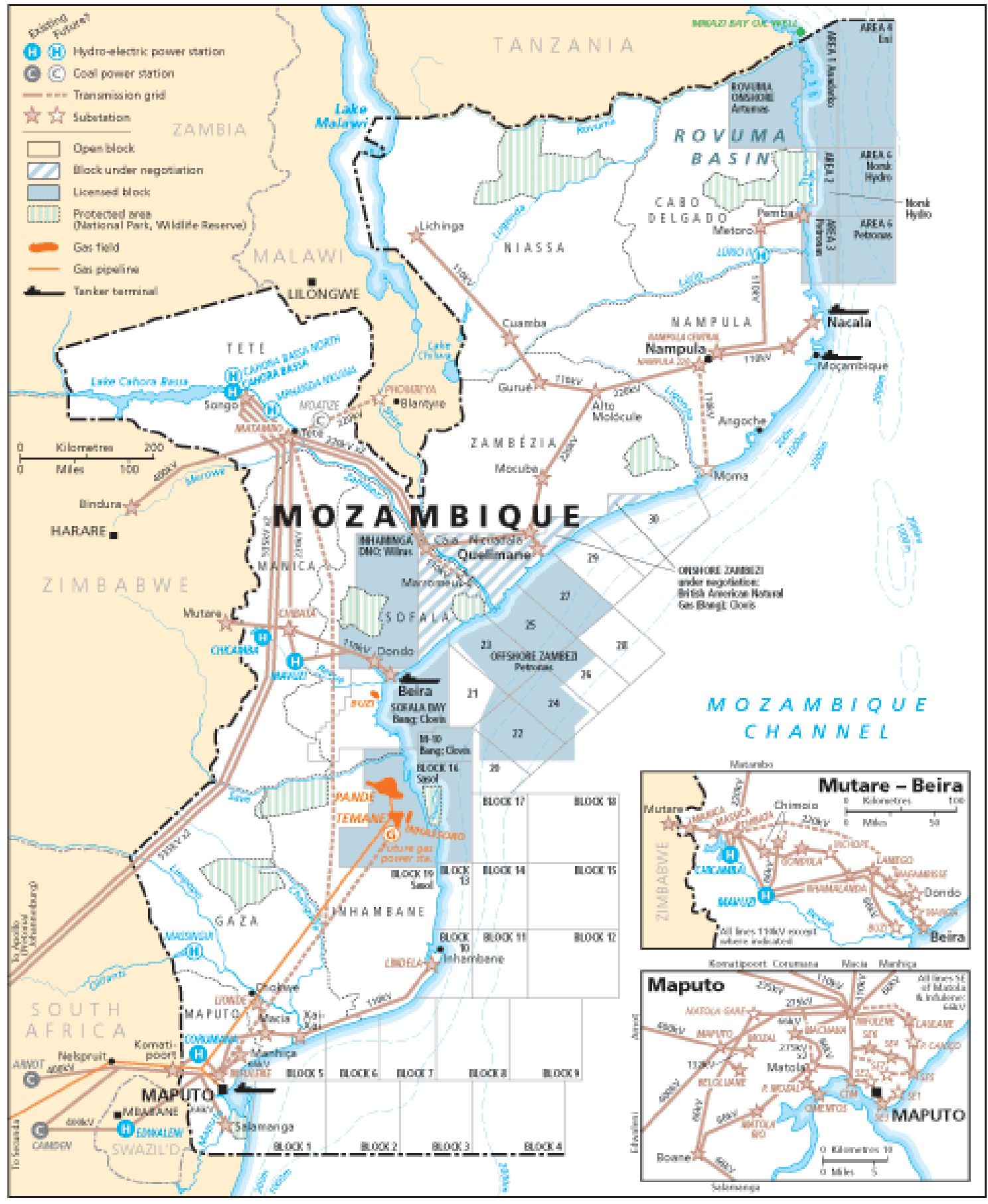

Source: Global Energy Network Institute. Available at:

http://geni.org/globalenergy/library/national energy grid/mozambique/mozambique nationalelectricitygrid.shtml [Accessed: 04/10/21] 
Since this study is focused on urban households, where access rates are typically higher ranging between 57 per cent (IEA, 2020) and 73 per cent (World Bank, 2021) depending on which data source is used, we explore the concept of energy transition from the perspective of renewable energy. Mozambique has significant potential for renewable energy, particularly from solar, hydro (from which over 50 per cent of EDM's supply is generated) and wind (FUNAE, 2013). However, the renewable energy market, particularly at the household level such as solar home systems, has only emerged in the last five years and faces many challenges such as sale of equipment in the informal market, of variable quality and without guarantees or assured installation (ALER, 2021). In addition, carbon-intensive cooking fuels, such as charcoal and wood, are commonly used in urban households (INE, 2021; Castán Broto et al., 2020).

We measure energy transition by the presence and extent of alternative sources of energy used by households. We asked, "Are there people within this ward or community that use other sources of electricity different than one supplied by the electricity company?' [IF YES] 'What sources are these?' Households that use alternatives such as solar, fuel-efficient biomass or clean cookstoves are deemed to contribute more towards the energy transition than those who use traditional (high carbon) solid fuels, such as firewood or charcoal. We also frame access to energy as a dimension of energy transition. Households that reported using low-carbon/fuel-efficient cooking fuels are deemed to contribute towards a transition away from traditional carbon-intensive fuel sources.

With respect to the possible drivers of energy poverty, income is measured by the average national minimum salary. Thus, it is contextual income rather than income reported by households themselves. Energy services are indicated by the functioning of the prepaid electricity system (known as Credelec). EDM launched this system in 1995, and since then it expanded rapidly to all major cities. For example, Baptista (2015) reported the Credelec user rate was 90 per cent in 2013 for Maputo City's residents with an electricity connection. We asked household respondents: 'How does the Credelec system function?' Place is indicated by the municipality where household interviews took place.

The interviews were transcribed and coded from where the data was analysed. Although in qualitative studies, as Blaike (2003: 20) observed, the 'data is recorded in words, remains in words throughout the analysis and findings are reported in words,' we apply some positivism to it (Mill, 2015; Feigl, 2020). If we say, for instance, that energy wellbeing is occurring through energy needs we will provide data evidence not just on what households said but also through the number of households that said so. For example, words like 'most' will be followed in parentheses by a number to provide a sense of proportion to the households studied.

\section{Findings}

\section{Energy poverty}

The data reveals that among the households that primarily use electricity for cooking (36), most mix electricity with other fuels including gas or charcoal (25), as electricity is less affordable for cooking, as described by three of our respondents:

"Electricity is very expensive. We don't cook beans on the electric stove we use charcoal; but other foods we use electricity to cook with." 1 
p. 9. The dynamics of urban household energy poverty and energy transition in Mozambique

"I usually only use electricity to boil water for tea, xima, rice. I never cook on the electric stove because it uses a lot of electricity. I cook with charcoal."2

"We cook on charcoal because it is cheaper. With this bag [of charcoal] I can use it for 15 days, but when I buy electricity it does not last."3

A relatively small number (11) of households reported that they use electricity as their dominant cooking fuel as they view its cost as similar to other cooking fuels. As one respondent stated:

"I cook everything [with electricity]... If I buy charcoal I will still need to buy electricity for lighting, so for the same amount I just buy electricity and use it to cook."

With respect to energy consumption, most households spend a lot on electricity per month. Of those who choose electricity for cooking and combine it with other fuels (25), about half (12) spend over $1000 \mathrm{MZN}$ on electricity monthly, with a quarter (7) spending below a thousand (500-1000 MZN) and another quarter (6) even lower (250-500 MZN). Of those who choose to cook with electricity as their main or dominant fuel (11), all spend over 1000 MZN. Most of those who do not use electricity for cooking, but instead use gas or combine gas with charcoal, also spend over $1000 \mathrm{MZN}$. Of those who use charcoal only (10), about half (4) spend over $1000 \mathrm{MZN}$ with the rest spending below.

On energy needs (using electricity for refrigeration, air conditioning and small businesses), 98 households reported that they use it for refrigeration (fridge or freezer). In terms of consumption, more than half (54) spend below $1000 \mathrm{MZN}$ on electricity per month while less than half (42) spend over this amount. That urban Mozambican households spend small amounts on electricity monthly is because they view that electricity for refrigeration is expensive. As householders reported:

"When I buy 50 meticais of electricity, I only have power for five days because of the fridge. In the past, 50 meticais of electricity would last for two to three weeks. But now every month I spend about 1,200 meticais because of the fridge, it uses a lot." 5

"The freezer is giving me a headache because I can recharge [the meter] with 200 [meticais] and it won't even last a week."6

Since urban households find electricity so expensive, they strategise and adjust their daily practices to restrict refrigeration use and switch off appliances, only using them when needed. As they put it:

"We turn the freezer off. I only connect it when I have something that needs to be frozen." 7

"I turn off the fridge during the day and only turn it on at night, so I can save."

Others go even further by switching off the entire house:

"Sometimes we turn off the meter to save electricity."

For the second aspect of energy needs (using electricity for air conditioning) 10 households responded that they use electricity for this purpose. Of these, all reported they spend over $1000 \mathrm{MZN}$ for electricity per month. And for the third aspect (using 
electricity for small businesses), of eight households who reported to do so, five spend over 1000 MZN per month.

Households' testimonies on the significance of electricity for small businesses are as follows:

"I have a metalwork business here at home... I depend on electricity for my livelihood. ${ }^{110}$

"I have a barraca here so I can support my children and the family. If I didn't have electricity for [refrigerating] soft drinks, beer or chickens I couldn't sell from home...my life is this business and I can do that because I have electricity." 11

"I have a popcorn machine, people come to buy popcorn and it enables me to buy bread. Electricity helps me a lot."12

In sum, these findings suggest that urban Mozambican households experience energy wellbeing to the extent that they have access to different cooking fuels ranging from electricity to charcoal, gas or firewood. They spend relatively a lot per month on electricity (more than half spend more than $1000 \mathrm{MZN}$ ) and they have varieties of energy needs.

\section{Explanatory factors}

The first possible factor explaining energy poverty we analyse is income level. We did not collect data on household income during the interviews, out of respect toward the sensitivities of household respondents in revealing information about their income to a stranger/interviewer. We therefore rely on contextual income data rather than reported data. Removing electricity expenditure (benchmarked in this study as 1,000 MZN per month) from the average minimum monthly salary, Mozambicans are left with very little (5,568 MZN) for other household needs. Knowing that income is low or very low and, as observed, access to energy, energy consumption and energy needs are relatively high, we find that income and energy poverty are not necessarily associated. On the one hand, we have low levels of income and on the other hand, energy wellbeing is occurring. This suggests that what drives and/or increases energy wellbeing in urban Mozambique households is another factor.

Second, we look at the effect of electricity service, as indicated by EDM's Credelec prepaid system. Almost all households reported the Credelec service being good for managing costs and how they use electricity. Below are some examples of the positive influence of the service:

"The [Credelec] system helps the poor, because if you don't have money for electricity, you just use candles. If you see that the situation is not good, you limit your use of electricity. The system helps us to save."13

"It is a good system because if a person has no money, you stay in the dark but without debt."14

"It is good because you only use what you can afford to pay for." 15

A few households, however, revealed problems, mainly associated with a system upgrade to new prepaid meters: 
"You cannot let the credit run out because the meter will disconnect and it will not allow you to recharge it which is a serious problem."16

"When the meter is zero and you want to recharge it, it does not accept. So, we either have to charge it from our neighbour or go to EDM to ask them to re-activate the system. It creates problems but, otherwise, it is a good system."17

Given the overall benefits that the Credelec system provides to households, the effect of electricity services contributes positively towards energy wellbeing.

The third factor explored is the effect of place. Households in municipalities governed by Frelimo (Maputo City and Matola) tend to cook with electricity as well as mixing it with other fuels more than those located in municipalities governed by opposition parties, including MDM (Beira) or Renamo (Nampula). As argued earlier, as Frelimo, the incumbent party nationally, shapes and implements the national electricity policy, along with maintaining close ties with the state-owned utility, EDM, it may favour energy wellbeing of its municipal residents by facilitating the delivery of electricity services within these municipalities. These municipalities also tend to concentrate more income providing their households with great purchasing power of goods and services than other cities. National enterprise censuses show that the Maputo region (inclusive of Maputo City and Matola) has higher levels of both firms and jobs than other parts of the country as well as increases in the percentage of firms from 28 per cent in 2002/3 to 35 per cent in 2015/6 while other regions remained about the same and/or even reduced (World Bank, 2018). Besides the choice of cooking fuels, the effect and significance of place is also evident on other measures of energy poverty, including electricity needed for air conditioning. Of the 10 surveyed households that use electricity for air conditioning, most are from Frelimo-held municipalities (Maputo City and Matola) rather than opposition-led ones (Beira and Nampula City).

\section{Energy Transition}

The presence of renewable energy in urban Mozambican households is low. The interviews reveal that many urban households use carbon-intensive cooking fuels: charcoal (10), gas (4) and firewood (2), with 11 reporting they use electricity for cooking, which in the Mozambican context is largely sourced from hydropower (UNDP, 2020). The majority (25) mix different fuel types to cook with, combining electricity with more carbonintensive (gas or charcoal) fuels.

By exploring other sources of electricity apart from that supplied by EDM, the most frequent response was that there are no other systems used for obtaining electricity everyone uses EDM electricity. A few respondents mentioned the use of solar panels, and some knew of others who used diesel powered generators, but the latter was mostly in the context of shops/small businesses having them as a backup system for when there are mains powers cuts.

Regarding solar energy, the majority responded that the use of solar panels did not exist in their neighbourhood, and that they had never heard of their use. Some commented that solar was mainly used in rural areas or, if they are used in urban areas, it is only as a temporary solution either when a person first moves into a property before an electricity connection to the main grid is established, or in a post-disaster recovery context. Notably, the post-disaster references were all made by respondents in Beira which, in March 2019, suffered the effects of tropical cyclone Idai which damaged a large part of the electricity grid infrastructure, along with roads, houses and agricultural land. In both circumstances, respondents noted that as soon as a grid connection was (re)established, the solar panels were no longer used, or were passed to someone else 
who lacked a grid connection. Only two households, both located in Matola, spoke of solar-powered water heaters being used in their neighbourhoods. However, these systems only provide heated water, they do not support other electrical appliances therefore a mains electricity grid connection is still required for other household electrical needs.

Household responses on the use of solar energy are as follows:

"People don't use solar here. They only used it last year because of [Cyclone] Idai, now they no longer use it." 18

"Here in Mahotas some use solar panels, but they use it simultaneously with EDM energy, the panel only heats water."19

"I had a solar panel but as soon as I got mains electricity, I gave it to a family member."20

"I, and others, had a solar panel but now, with electricity, nobody uses it anymore. I took mine to my machamba [area for subsistence farming]. But there is already electricity there now, so there is no use for it anymore." 21

In sum, these findings suggest only limited numbers of urban Mozambican households use renewable or low-carbon fuel sources. Those who use them are mostly in a post-disaster recovery context or in another form of temporary usage.

\section{Discussion}

That urban Mozambican households enjoy energy wellbeing reflects the uneven development in the country (as seen in Figure 2) whereby urban centres are where basic sociotechnical infrastructure, such as roads and grid networks are concentrated, businesses operate and demand electricity.

However not all urban locations reap the same benefits, with those located in municipalities governed by opposition parties likely to be more exposed to energy poverty. This could be reflective of Mozambique's development trajectory which has been shaped by its colonial past and geographical constraints. Beira and Nampula city municipalities are physically distant from the capital in the south and have historically received less investment and have more fragmented infrastructure (Baptista, 2015; Cotton et al., 2019).

In addition, the measures used to analyse energy poverty in this paper are only one part of a dynamic and complex picture. Household income and expenditure levels, for example, are not static and Mozambican households have been experiencing a backsliding in available income, with the recent 2019/2020 household expenditure survey showing that Mozambicans were on average spending 19 per cent less on housing, water and energy costs than five years prior in 2014/2015 (INE, 2021). This could have quite significant consequences for energy poverty in the country. Even though high numbers of urban households have an electricity connection, whether they can afford to pay for the electricity services they desire and require is something that requires ongoing investigation.

Other factors influencing household fuel choices or energy consumption patterns include the quality and reliability of electricity supply, spatial variables such as the built environment, electricity tariffs or cultural and generational factors, among others. The 
quality of Mozambique's grid-supplied electricity is considered poor, ranking $114^{\text {th }}$ out of 137 countries (UNDP, 2020). Studies such as Salite et al. (2021) describe how urban centres in Mozambique suffer from unreliable electricity services, which can drive households to use gas and charcoal rather than increase their electricity usage. Castán Broto et al. (2020), whilst investigating the use of charcoal among affluent urban residents in Maputo, found that urban households tend to use multiple energy sources as part of complex 'fuel stacking' choices. Baptista (2015) examined how households adjust their electricity consumption to meet financial resources available by combining charcoal with limited use of electricity, purchased via Credelec.

The responses in this study support the notion that many urban households, facilitated through the prepaid Credelec system, monitor their electricity expenditure, and rationalise their electricity use to not only save money but simultaneously becoming more energy efficient either by using appliances less or acquiring more energy-efficient equipment such as low-energy lightbulbs. This rationalisation of electricity use is undertaken based on what other fuel sources are available and affordable to individual households. However, as Baptista (2015) notes, whilst the prepaid system has the potential to tackle energy poverty among energy-vulnerable populations, it does not address the underlying inequalities and injustices of uneven development that exist within individual urban locations, such as Maputo City, or between urban locations across the country. As Baptista (2015: 1017) states: 'Prepayment offers a promise of future consumption for those who can buy electricity credit, but not the security that electricity will be available for consumption or that it can be consumed regularly and liberally by every household connected to the grid'.

Turning to energy transitions, the use of renewable energy sources in urban households is low. Most urban households, even though they have electricity access, continue to use carbon-intensive cooking fuels (gas and charcoal) either as their dominant cooking fuel or mixed with other fuel types. Further, the use of biomass fuels (wood, peat, charcoal) is implicated in the rise in urban air pollution that affects cardiovascular and respiratory health (Das et al., 2017), thus widening the inequalities produced by energy poverty. However, the use of cleaner renewable alternatives for domestic energy service provision such as solar panels in urban settings remains uncommon. Some of the barriers of uptake, illustrated by the household responses, are the limited energy services that renewable energy sources provide (limited to lighting, hot water or phone charging), the cost to purchase these systems, or simply a lack of awareness that these systems exist for urban households as a longer term means of accessing electricity.

Although the energy transition appears to be limited in Mozambique at the urban household level, viewed from the national level Mozambique's energy transition seems more advanced but its future prospects remain uncertain. Currently the majority (52 per cent) of electricity supplied by EDM is hydroelectricity bought from Cahora Bassa Hydroelectric dam (EDM, 2020b). While EDM produces its own electricity at a level of 12 per cent, part of it is from other hydroelectric sources (hydroelectric centrals) and the remaining is from thermoelectric generator parks powered by gas and/or diesel.

Yet 35 per cent of electricity produced in the country is from natural gas bought from Independent Power Producers (IPPs) through three thermoelectric centrals, namely: CTRG, Gigawatt and Kuvaninga (EDM, 2018). In the coming years, IPPs are expected, on the one hand, to better contribute towards a low-carbon energy transition with the operation of large-scale solar power plants in Mocuba and Metoro (ibid). This will be complemented by a strategy of decentralised generation, operating off the main grid, and shaped by a recognition of the limits of grid extension and by donor priorities for addressing energy poverty and climate mitigation. The latter is implemented by Fundo de Energia (FUNAE) to promote access to electricity through funding and implementing 
off-grid power production systems, specifically solar PV standalone systems and minigrids, mini-hydropower and biomass. However, the primary focus is rural electrification and so far, less than one per cent of households have benefited from off-grid connections (Cotton et al., 2019), as FUNAE has mostly focused on electrifying schools, hospitals, administrative offices and pumping stations with solar panels (Kirshner et al., 2019).

On the other hand, IPPs are expected to stall, or even reverse, the clean energy transition, as a coal based thermoelectric IPP is being planned in Moatize, in Tete province, where coal extraction has been taking place since the late-2000s (EDM, 2018). Northern Mozambique also has significant offshore gas reserves in development in the Rovuma basin which have the potential for the country to become the largest gas producer in sub-Saharan Africa (IEA, 2019). Despite this EDM's 2018-2028 strategy also prioritises implementation of the Mphanda Nkuwa hydroelectric dam and to attract more investments, besides the Mocuba and Metoro solar farm efforts (EDM, 2018).

Notwithstanding the debates about whether it is morally appropriate for low-income countries, such as Mozambique which has contributed so little to global greenhouse gas emissions, to forego the development of carbon-rich energy resources (see Zitamar, 2021; Greiner, 2021), a low-carbon energy transition would make a significant contribution towards achieving universal access. However, the scale of the low-carbon transition remains in flux.

\section{Conclusions}

This study on the dynamics of urban households' energy poverty in Mozambique reveals that, overall, urban households tend to exhibit energy wellbeing within a context where energy use and expenditure levels are low. Urban Mozambican households experience energy wellbeing to the extent that they have access to a range of cooking fuels (electricity, charcoal, gas and/or firewood), they spend relatively a lot per month on electricity, and they have varied energy needs.

By analysing the effects of possible factors influencing energy poverty, studies found that increases in income lead to higher levels of energy consumption (Castán Broto et al., 2020, Barnes et al., 2011; Okushima, 2016). However, we found that income does not affect the measures of energy poverty we used in this study. Mozambicans are characterised by relatively low incomes compared to citizens of neighbouring countries in Southern and Eastern Africa, but they do well to reduce energy poverty through access to varieties of fuels to cook with, spending cash on electricity, and using electricity for a range of needs. This difference might be accounted for by the difference in the forms of data: qualitative versus quantitative. Those studies using quantitative data may be in a better position to classify and categorise the variables. Our study is exploratory in nature.

We found that electricity service types play an important role in the experience of energy poverty. The Credelec prepaid system has had a positive impact. As most households testified, it enables households to better control the usage of electricity: it is easier to use, it does not lead to debt or fines for non-payment, and it enables you to save electricity or be more fuel efficient. With the Credelec system, more households enjoy electricity autonomy now than before.

The effect of place, analysed by the governing political party of that place, was confirmed. We found that urban households in municipalities ruled by the dominant party Frelimo tend to enjoy more energy wellbeing than those ruled by opposition parties: MDM in Beira and Renamo in Nampula City. As the energy policy is mainly shaped by the dominant party Frelimo, Frelimo also controls its implementation favouring the municipalities that Frelimo govern. However further research is required to determine 
whether these differences are solely a reflection of the governing political party at the municipality level or whether historical factors of colonial legacy and uneven development across the country also matter. Analysis of additional urban locations in the centre and north of the country, including those governed by Frelimo, would assist in unpacking this issue.

On energy transition, we found little evidence that Mozambique's urban households are shifting toward renewable energy sources. Most households reported they cook with high-carbon fuels (charcoal, gas and firewood) confirming the evidence from other studies on energy use in Mozambique (Baptista, 2015; Castán Broto et al., 2020). In addition, renewable sources, such as solar panels, are not considered by urban households as long-term solutions for energy provision, partly because of the capacity limitations of the appliances they can support or energy services they can provide (mainly limited to heating water, lighting and charging small devices like mobile phones). At the national scale, the majority of Mozambique's electricity currently comes from hydroelectric sources and there are a variety of energy projects in development across the carbon spectrum including solar power plants, a new hydroelectric dam but also coal and gas. As such the government's energy policy only really promotes solar systems to improve rural electrification, led by FUNAE, as opposed to being integrated into urban energy systems. Therefore, a change in policy strategy towards renewable development in urban locations is warranted. Further research into the potential incentives and barriers for how renewable energy could be integrated into urban energy systems and improve energy wellbeing in Mozambique is needed.

Finally, energy poverty is a complex and dynamic social policy priority. The experiences of Mozambican households are in flux, as the political dynamics of energy transition, changing income levels and electrification strategy generate complexity within the energy landscape of the society. How the benefits of modern energy service provision are distributed across urban and rural communities, Frelimo-affiliated and MDM/Renamo-affiliated municipalities, between prepaid meter users, or between grid connected versus micro-renewable using households, is rapidly shifting, with new 'winners and losers' emerging. It is this element of energy justice, embedded in complex socio-technical dynamics of rapid transition that requires longer-term monitoring (not least in the wake of the Covid-19 pandemic that occurred after data collection in this paper). Understanding energy poverty in Mozambique therefore required not only an understanding of changing household income and expenditure to derive vulnerability, but also a deeper understanding of social capacity and autonomy over fuel choice, embedded within a place-based political system of energy service provision.

\author{
Notes \\ 1 Interview from Muhalaze, Matola. \\ 2 Interview from Natikiri, Nampula City. \\ 3 Interview from Nkobe, Matola. \\ 4 Interview from Mahotas, Maputo City. \\ 5 Interview from Mutawanha, Nampula City. \\ 6 Interview from Dlavela, Matola. \\ 7 Interview from Carrupeia, Nampula City. \\ 8 Interview from Manga, Beira.
}


9 Interview from Namicopo, Nampula City.

10 Interview from Pioneiros, Beira.

11 Interview from Mafalala, Maputo City.

12 Interview from Dlavela, Matola.

13 Interview from Dlavela, Matola.

14 Interview from Munhava, Beira.

15 Interview from Muhalaze, Matola.

16 Interview from Magoanine, Maputo City.

17 Interview Muhaivire, Nampula City.

18 Interview from Chota, Beira.

19 Interview from Mahotas, Maputo City.

20 Interview from Nkobe, Matola.

21 Interview from Malhapsene, Matola.

\section{Acknowledgements}

This research was conducted as part of the project: A Political- Economic Analysis of Electricity Grid Access Histories and Futures in Mozambique (POLARIZE), funded through the Applied Research Programme on Energy for Economic Growth (EEG) led by Oxford Policy Management (project number A0534A), and funded by the UK Government, through UK Aid - UK Foreign, Commonwealth and Development Office (FCDO). The views expressed in this research do not necessarily reflect the UK government's official policies.

\section{Author Details}

*Corresponding author: Carlos Shenga, Centre for Research on Governance and Development, Mozambique and University Joaquim Chissano, Mozambique. cshenga@cpgd.org.mz

\section{Other authors:}

- Matthew Cotton, Teesside University, UK. M.Cotton@tees.ac.uk

- Joshua Kirshner, University of York, UK. Joshua.kirshner@york.ac.uk

- Lorraine Howe, Centre for Research on Governance and Development, Mozambique. Ihowe@cpgd.org,mz

\section{References}

Abi Ghanem, D. (2018) Energy, the city and everyday life: Living with power outages in post-war Lebanon. Energy Research \& Social Science, 36, 36-43.

ALER (2021) Renewables in Mozambique: Briefing 2021. The Lusophone Renewable Energy Association and the Mozambican Renewable Energy Association in cooperation with GET.invest Mozambique. Available at: https://www.aler- 
p. 17. The dynamics of urban household energy poverty and energy transition in Mozambique

renovaveis.org/en/activities/publications/other/download-the-briefing-andanimations/ [Accessed: 30/09/2021].

Ambrose, A. and Marchand, R. (2017) The contemporary landscape of fuel poverty research. Indoor and Built Environment, 26, 7, 875-878.

Baptista, I. (2015) We Live on Estimates: Everyday Practices of Prepaid Electricity and the Urban Condition in Maputo, Mozambique. International Journal of Urban and Regional Research, 39, 5, 1004-1019.

Barnes, D., Khandker, S. and Samad, H. (2011) Energy poverty in rural Bangladesh. Energy Policy, 39, 2, 894-904.

Bellinger, N. (2021) Political parties and citizens' wellbeing among non-democratic developing countries. Party Politics, 27,6, 1144-1154.

Birol, F. (2007) Energy Economics: A Place for Energy Poverty in the Agenda?. The Energy Journal, 28, 3.

Blaike, N. (2003) Analysing Quantitative Data. From Description to Explanation. Los Angeles, CA: Sage Publications.

Boris, S. (2010) Socio-cultural dimensions in household cooking energy choice: Implications for energy transition in Catembe, Mozambique. Master thesis, Department of Human Geography. Faculty of Social Sciences, Stockholm University, Sweden.

Borowski, P.F. (2021) Significance and directions of energy development in African countries. Energies, 14, 15, 4479.

Bouzarovski, S. (2014) Energy poverty in the European Union: landscapes of vulnerability. Wiley Interdisciplinary Reviews: Energy and Environment 3, 3, 276 289.

Bouzarovski, S. (2018) Understanding energy poverty, vulnerability and justice. In: Energy Poverty. Palgrave Macmillan, Cham, 9-39.

Brand-Correa, L.I. and Steinberger, J.K. (2017) A framework for decoupling human need satisfaction from energy use. Ecological Economics, 141, 43-52.

Brisbois, M.C. (2020) Decentralised energy, decentralised accountability? Lessons on how to govern decentralised electricity transitions from multi-level natural resource governance. Global Transitions, 2, 16-25.

Bronfman, N.C., Jiménez, R.B., Arevalo, P.C. and Cifuentes, L.A. (2015) Public acceptance of electricity generation sources: The role of trust in regulatory institutions. Energy \& Environment, 26, 3, 349-368.

Castán Broto, V., Arthur, M. and Guibrunet, L. (2020) Energy profiles among urban elite households in Mozambique: Explaining the persistence of charcoal in urban areas. Energy Research \& Social Science, 65.

Castán Broto, V., Baptista, I., Kirshner, J., Smith, S. and Alves, S. N. (2018) Energy justice and sustainability transitions in Mozambique. Applied Energy, 228, 645-655.

Chaurey, A., Ranganathan, M. and Mohanty, P. (2004) Electricity access for geographically disadvantaged rural communities-technology and policy insights. Energy Policy, 32, 15, 1693-1705.

Cotton, M., Kirshner, J. and Salite, D. (2021) The Politics of Electricity Access and Environmental Security in Mozambique. In: Asif M. (ed.) Energy and Environmental Security in Developing Countries. Cham: Springer, 279-302.

Cotton, M., Kirshner, J. and Salite, D. (2019) The political economy of electricity access: Lessons from Mozambique. Applied Research Programme on Energy and Economic Growth, Energy Insight Paper. Available at: https://energyeconomicgrowth.org/publication/political-economy-electricityaccess-lessons-mozambique [Accessed: 30/09/2021].

Cresswell, T. (2014) Place: an introduction. London: Wiley.

Das, I., Jagger, P. and Yeatts, K. (2017) Biomass cooking fuels and health outcomes for women in Malawi. Ecohealth, 14, 1, 7-19. 
EDM (2018) Estratégia da EDM 2018-2028. Electricidade de Moçambique. Available at: https://portal.edm.co.mz/sites/default/files/documents/Reports/ESTRATEGIA E DM_2018_2028.pdf [Accessed: 30/09/2021].

EDM (2020a) Official launch of electrification of 19 administrative posts. Electricidade de Moçambique. Available at: https://www.edm.co.mz/en/node/3167 [Accessed: 30/09/2021].

EDM (2020b) Relatório Annual de Actividades do Conselho de Administração 2019. Electricidade de Moçambique. Available at: https://www.edm.co.mz/pt/document/reports-reports-andaccounts/relat\%C3\%B3rio-e-contas-de-2019-0 [Accessed: 30/09/21].

Feigl, H. (2020) Positivism. Encyclopaedia Britannica. Available at: https://www.britannica.com/topic/positivism [Accessed: 30/09/2021].

Finscope (2020) Mozambique Finscope Consumer Survey Report 2019. Finmark Trust. Available https://finmark.org.za/system/documents/files/000/000/155/original/Mozamb ique_Survey-2020-07-311.pdf?1597303567 [Accessed: 30/09/2021].

FUNAE (2013) Renewable Energy Atlas of Mozambique. Fundo de Energia, Moçambique. Available at: https://gestoenergy.com/wpcontent/uploads/2018/04/MOZAMBIQUE-RENEWABLE-ENERGY-ATLAS.pdf [Accessed: 30/09/2021].

Goodin, R. E. and Tilly, C. (2006) The Oxford Handbook of Contextual Political Analysis. Oxford, UK: Oxford University Press.

Greiner, P.T. (2021) How colonialism's legacy makes it harder for countries to escape poverty and fossil fuels today. The Conversation. Available at: https://theconversation.com/how-colonialisms-legacy-makes-it-harder-forcountries-to-escape-poverty-and-fossil-fuels-today-159807 [Accessed: 31/10/21]

Herrington, M.J., Lant, P.A., Smart, S., Greig, C. and van de Fliert, E. (2017) Defection, recruitment and social change in cooking practices: Energy poverty through a social practice lens. Energy Research \& Social Science, 34, 272-280.

IEA (2019) Mozambique Energy Outlook. International Energy Agency. Available at: https://www.iea.org/articles/mozambique-energy-outlook [Accessed: 05/10/21].

IEA (2020) World Energy Outlook 2020. International Energy Agency. Available at: https://www.iea.org/reports/world-energy-outlook-2020 [Accessed: 30/09/21].

Imami, D., Lami, E., Zhllima, E., Gjonbalaj, M. and Pugh, G. (2020) Closer to election, more light: electricity supply and elections in a post conflict transition economy. Post-Communist Economies, 32, 3, 376-390.

INE (2019) IV Recenseamento Geral da População e Habitação. Resultados Definitivos 2017. Instituto Nacional de Estatística. Available at: http://www.ine.gov.mz/ivrgph-2017/mocambique/censo-2017-brochura-dos-resultados-definitivos-do-ivrgph-nacional.pdf [Accessed: 30/09/2021].

INE (2021) Inquérito sobre Orçamento Familiar 2019/20. Instituto Nacional de Estatística. Available at: http://www.ine.gov.mz/operacoesestatisticas/inqueritos/inquerito-sobre-orcamento-familiar/iof-2019-20/inqueritosobre-orcamento-familiar-iof-2019-20/view [Accessed: 01/10/2021].

Kirshner, J., Baker, L., Smith, A. and Bulkeley, H. (2019) A regime in the making? Examining the geographies of solar PV electricity in Southern Africa. Geoforum, 103, 114-125.

Mattes, R. (2008) The Material and Political Bases of Lived Poverty in Africa: Insights from the Afrobarometer. In: Møller, V., Huschka, D. and Michalos, A.C. (eds) Barometers of Quality of Life Around the Globe. Social Indicators Research Series, 33, Springer, Dordrecht.

Mattes, R. (2020) Lived poverty on the rise: decades of living-standard gains ends in Africa. Afrobarometer Policy Paper 62. Available at: 
p. 19. The dynamics of urban household energy poverty and energy transition in Mozambique

https://afrobarometer.org/sites/default/files/publications/Policy\%20papers/ab r7 pap13 lived poverty on the rise in africa 1.pdf [Accessed: 30/09/2021].

Mensah, K.E., Damnyag, L. and Kwabena, N.S. (2020) Analysis of charcoal production with recent developments in Sub-Sahara Africa: a review. African Geographical Review, 1-21.

Meyer, B., and Sullivan, J. (2003) Measuring the Wellbeing of the Poor Using Income and Consumption. The Journal of Human Resources, 38, 1180-1220.

Mill, J. (2015) Auguste Comte and Positivism. Cambridge University Press.

Mulenga, B.P., Tembo, S.T. and Richardson, R.B. (2019) Electricity access and charcoal consumption among urban households in Zambia. Development Southern Africa, 36, 5, 585-599.

Nussbaumer, P., Bazilian, M., and Modi, V. (2012) Measuring energy poverty: Focusing on what matters. Renewable and Sustainable Energy Reviews, 16, 1, 231-243.

Ochoa, R. and Graizbord Ed, B. (2016) Privation of energy services in Mexican households: An alternative measure of energy poverty. Energy Research \& Social Science, 18, 36-49.

Okushima, S. (2016) Measuring energy poverty in Japan, 2004-2013. Energy Policy, 98, 557-564.

Oliveras, L., Artazcoz, L., Borrell, C., Palència, L., López, M., Gotsens, M., Peralta, A. and Marí-Dell'Olmo, M. (2020) The association of energy poverty with health, health care utilisation and medication use in southern Europe. SSM - Population Health, $12,100665$.

Pachauri, S. and Spreng, D. (2003) Energy Use and Energy Access in Relation to Poverty. ETH Zurich: Center for Energy Policy and Economics, Working paper series 39.

Papada, L. and Kaliampakos, D. (2020) Being forced to skimp on energy needs: A new look at energy poverty in Greece. Energy Research \& Social Science, 64, 101450.

Power, M., Newell, P., Baker, L., Bulkeley, H., Kirshner, J. and Smith, A. (2016) The political economy of energy transitions in Mozambique and South Africa: The role of the Rising Powers, Energy Research \& Social Science, 17, 10-19.

Power, M. and Kirshner, J. (2019) Powering the state: The political geographies of electrification in Mozambique. Environment and Planning C: Politics and Space, 37, 3, 498-518.

Ruggeri Laderchi, C., Saith, R. and Stewart, F. (2003) Does it matter that we do not agree on the definition of poverty? A comparison of four approaches. Oxford Development Studies, 31, 3, 243-274.

Rutherford, J. and Coutard, O. (2014) Urban energy transitions: places, processes and politics of socio-technical change. Urban Studies, 51, 7, 1353-1377.

Salazar, D., Castán Broto, V. and Adams, K. (2017) Urban Infrastructure and Energy Poverty in Maputo, Mozambique. In: Allen A., Griffin L., Johnson C. (eds) Environmental Justice and Urban Resilience in the Global South. Palgrave Macmillan, New York.

Salite, D., Kirshner, J., Cotton, M., Howe, L., Cuamba, B., Feijó, J. and Macome, A. (2021) Electricity access in Mozambique: A critical policy analysis of investment, service reliability and social sustainability. Energy Research \& Social Science, 78.

Samarakoon, S. (2019) A justice and wellbeing centered framework for analysing energy poverty in the Global South. Ecological Economics, 165, 106385.

Schmidt, T.S., Matsuo, T. and Michaelowa, A. (2017) Renewable energy policy as an enabler of fossil fuel subsidy reform? Applying a socio-technical perspective to the cases of South Africa and Tunisia. Global Environmental Change, 45, 99-110.

Shenga, C. (2020) The Role of Political parties on Partisanship. In: Oscarsson, H. and Holmberg, S. (eds.) Research Handbook on Political Partisanship. Cheltenham, UK: Edward Elgar. 
Tarekegne, B. (2020) Just electrification: Imagining the justice dimensions of energy access and addressing energy poverty. Energy Research \& Social Science, 70, 101639.

Therborn, G. (2009) Why and How Place Matters. In: Goodin, R. (ed) The Oxford Handbook of Political Science. Oxford: The Oxford University Press.

Thomassen, J. (2020) Party government and democracy. In: Oscarsson, H. and Holmberg, S. (eds.) (2020) Research Handbook on Political Partisanship. Cheltenham, UK: Edward Elgar.

UNDP (2020) Mozambique energy and the poor: Unpacking the investment case for clean energy. United Nations Development Programme. Available at: https://www.africa.undp.org/content/rba/en/home/library/UNDP-UNCDFeSwatini-Energy-and-the-Poor-Unpacking-the-investment-case-for-cleanenergy.html [Accessed: 30/09/21].

Wagelndicator (2021) Minimum salary in Mozambique between 1 April 2018 and 31 March 2019. Available at: https://meusalario.org/mocambique/salario/salariominimo/archive-before-2019/salario-minimo-em-mocambique-a-partir-de-01-042018-a-31-03-2019 [Accessed: 30/09/2021].

Williams, S. and Short, M. (2020) Electricity demand forecasting for decentralised energy management. Energy and Built Environment, 1, 2, 178-186.

World Bank (2017) State of Electricity Access Report. Washington DC, USA: World Bank Group.

World Bank (2018) Mozambique Poverty Assessment. World Bank, Washington, D.C. Available https://documents1.worldbank.org/curated/en/248561541165040969/pdf/M ozambique-Poverty-Assessment-Strong-But-Not-Broadly-Shared-Growth.pdf [Accessed: 30/09/2021].

World Bank (2021) World Development Indicators. World Bank, Washington, D.C. Available at: https://databank.worldbank.org/source/africa-developmentindicators [Accessed: 07/10/21].

Ugembe, M. A., Brito, M. C. and Inglesi-Lotz, R. (2021) Measuring energy poverty in Mozambique: is energy poverty a purely rural phenomenon? Available at: https://iaee2021online.org/download/contribution/fullpaper/94/94_fullpaper_2 0210615_205215.pdf [Accessed: 14/12/2021].

Zitamar (2021) Snake or ladder: Is gas the best route to development in Mozambique?. Zitamar News. Available at: https://zitamar.com/snake-ladder-gas-best-routedevelopment-mozambique/ [Accessed: 28/10/21]. 